Наносистели, нанолатеріали, нанотехнології Nanosistemi, Nanomateriali, Nanotehnologii 2018, т. 16, № 2, сc. 413-424 (c) 2018 ІМФ (Інститут металофізики ім. Г. В. Курдюмова НАН України) Надруковано в Україні. Фотокопіювання дозволено тільки відповідно до ліцензії

PACSnumbers: 66.20.Ej, 68.08.Bc, 68.37.Hk, 81.07.Bc, 81.10.Dn, 81.16.Be, 81.16.Dn

\title{
Growth of Gold Nanoprisms on Freshly Cleaved Mica Surface
}

\author{
T. I. Borodinova, V. I. Styopkin*, A. A. Vasko*, V. E. Kutsenko*, and \\ O. A. Marchenko*
}

F. D. Ovcharenko Institute of Biocolloidal Chemistry, N.A.S. of Ukraine, 42 Academician Vernadsky Blvd., UA-03142 Kyiv, Ukraine

"Institute of Physics, N.A.S. of Ukraine, 46 Nauky Ave.,

UA-03028 Kyiv, Ukraine

A numerous methods are being used for synthesis of gold nanoparticles (NPs) in liquid media, in micelles, and at different interfaces. The size and geometry of NPs depend on parameters of synthesis. Here, we propose the modified polyol method of synthesis of Au NPs on freshly cleaved mica surfaces. In such conditions, the nanoprisms (NPrs) and nearly spherical NPs are being simultaneously formed on the mica substrate. We have determined the parameters of synthesis, with which preferential formation of NPrs is being realized. The percentage of NPrs depends on the surface conditions, in particular, on wettability of the surface by growth medium. We demonstrate that both the size and the morphology of grown NPs can be controlled by means of components of growth medium and parameters of synthesis.

Для синтези наночастинок (НЧ) золота у рідких середовищах, міцелах і на твердих підкладинках застосовуються різні методи. Від параметрів синтези залежать розмір і геометрія НЧ. Ми пропонуємо модифіковану поліольну методу синтези НЧ золота на поверхні свіжосколеної слюди. За таких умов на поверхні підкладинки одночасно утворюються нанопризми (НПр) золота та НЧ із формою, близькою до сферичної. Встановлено параметри синтези, за яких формування НПр є домінувальним. Відсоток НПр залежить від стану поверхні слюди, зокрема, від її змочуваности ростовим середовищем. Показано, що розмір і морфологія вирощених НЧ безпосередньо контролюються складом ростового середовища та параметрами синтези.

Для синтеза наночастиц (НЧ) золота в жидких средах, мицеллах и на твёрдых подложках применяются различные методы. От параметров синтеза зависят размер и геометрия НЧ. Мы предлагаем модифицированный полиольный метод синтеза НЧ золота на поверхности свежесколотой 
слюды. В таких условиях на поверхности подложки одновременно образуются нанопризмы (НПр) золота и НЧ с формой, близкой к сферической. Установлены параметры синтеза, при которых формирование НПр является преобладающим. Процент НПр зависит от состояния поверхности слюды, в частности, от её смачиваемости ростовой средой. Показано, что размер и морфология выращенных НЧ непосредственно контролируются составом ростовой среды и параметрами синтеза.

Key words: mica, nanoparticles, nanoprisms, gold, polyol synthesis.

Ключові слова: слюда, наночастинки, нанопризми, золото, поліольна синтеза.

Ключевые слова: слюда, наночастицы, нанопризмы, золото, полиольный синтез.

(Received 24 March, 2018)

\section{INTRODUCTION}

Gold nanoparticles (NPs) have received considerable research interest in the last decades. Due to unique physical and chemical properties, $\mathrm{Au}$ NPs are widely used in medicine [1-6], optoelectronics [7-13], catalysis [14-16], STM and SERS researches [17-20]. The most of studies are focused on the synthesis of gold NPs in aqueous and non-aqueous media, in the micelles and at the phase interfaces. Considerably less attention has received the formation of monocrystalline NPs with regular shape (so-called 'nanoprisms'-NPrs) on solid surfaces. The authors of [18] reported growth of gold nanowires and nanoplates in aqueous media in presence of cetyltrimethylammonuim bromide on the glass surface coated by indium tin oxide. In [21, 22], gold NPrs have been synthesized on solid substrates ( $\mathrm{Si}$, glass, stainless steel, polyimide, polydimethylsiloxane (PDMS), mica, graphite, etc.) using a single step thermolysis of $\left(\mathrm{AuCl}_{4}\right)^{-}$-tetraoctylammonium bromide complex in air.

To obtain Au NPrs, one- and multistage methods of synthesis are used. Nucleus method of NPrs formation was proposed in [23-25] and modified in [26, 27]. Therefore, all stages can be summarised as formation of nuclei $\rightarrow$ changing the conditions of the growth medium $\rightarrow$ adding nuclei to growth medium $\rightarrow$ formation of NPrs. However, result of such synthesis is a mixture of spherical and anisotropic nanostructures, and it needs additional separation of particles.

Among one-stage methods, one can distinguish biosynthesis, photoreduction, thermal method, polyol synthesis. Products of the vital activity of microorganisms [28, 29], extracts of plants [30], fungi [31] are used as reductions of $\mathrm{Au}$ ions and stabilizers of NPrs during bio- 
synthesis. Photoreduction requires presence of photocatalyst, stabilizer and a substance that is an electron donor in a growth medium [32]. Thermal and polyol methods allow controlling size of NPrs via (i) changing the concentration ratio of precursor/stabilizer, (ii) the time of synthesis and (iii) temperature [33]. In polyol synthesis, ethylene glycol (EG) is used as a dispersion medium and reducing agent of $\mathrm{Au}$ ions, PVP or mixture of PVP + cetyl trimethylammonium bromide (CTAB) [34-36] are used as stabilizers. However, this synthesis undergoes at high temperatures $\left(120-195^{\circ} \mathrm{C}\right)$. In [37], the flat Au nanocrystals with triangular and hexagonal shape and thickness less than $100 \mathrm{~nm}$ formed in the free volume of the mixture ethanol, ethylene glycol, $\mathrm{HAuCl}_{4}$ (a precursor of gold) and $\mathrm{PVP}$ at $80^{\circ} \mathrm{C}$.

In this paper, we highlight that immersing of freshly cleaved mica plates into growth medium of [37] drastically changes the character of growth of Au nanostructures. In such conditions, the NPrs and NPs are being simultaneously formed on mica surface. The preferential formation of NPrs on mica substrate is achieved by adding glycerine to the solution, increasing of duration of synthesis and concentration $\mathrm{Au}$ ions.

\section{MATERIALS AND METHODS}

Chloroauric acid $\left(\mathrm{HAuCl}_{4} \cdot 3 \mathrm{H}_{2} \mathrm{O}\right.$, 'Shanghai Synnad Fine Chemical Co., LTD'), ethyl alcohol, polyvinylpyrrolidone (29 kDa, 'Sigma-Aldrich'), ethylene glycol ('Reahim', Russia) and glycerine ('Sigma-Aldrich') were used to synthesize gold particles on the freshly cleaved surface of mica.

The morphology of resulted gold nanostructures and chemical composition were studied by scanning electron microscope (JSM-6060), electron probe $\mathrm{x}$-ray spectral microanalysis (x-ray microanalyzer JXA733 with energy dispersive $\mathrm{x}$-ray spectrometer (EDS)). Estimation of the chemical composition via the EDS was performed with the following parameters and analytical characteristics: accelerating voltage of $20 \mathrm{kV}$, beam current $20 \mathrm{nA}$, spectral resolution $140 \mathrm{eV}$ at $\mathrm{Mn} K_{\alpha}$ line, spatial resolution $-1-5$ microns.

The reference samples were: $\mathrm{Si}, \mathrm{Al}, \mathrm{Mg}, \mathrm{FeO}\left(\mathrm{SiO}_{2}, \mathrm{Al}_{2} \mathrm{O}_{3}, \mathrm{MgO}, \mathrm{FeO}\right.$, biotite), Mn (metal $\mathrm{Mn})$, Ti (ilmenite), $\mathrm{Au}(\mathrm{Au})$; recalculations method-ZAF (atomic number $Z$, absorption $A$, fluorescence $F$ ), detection limit-0.01-0.1\%.

The study of wettability of freshly cleaved mica substrate by the growth-medium components was carried out by contact angle (CA) measurements. The droplet of each component was deposited on the mica surfaces and annealed $\mathrm{Au}(111)$. The volume of deposited droplets was $2 \mu \mathrm{L}$. The value of the contact angle was averaged based on 5 measurements. The error of measured wetting angle was within $\pm 5^{\circ}$. 


\section{RESULTS AND DISCUSSION}

Synthesis I. Preparation of growth medium: $15 \mathrm{ml}$ of EG was mixed with $1.6 \mathrm{ml}$ of ethanol (ET). Then, $2 \mathrm{ml}$ of PVP $C=0.45 \mathrm{M}$ (molar concentration per polymer repeating unit) and $1.4 \mathrm{ml}$ of $\mathrm{HAuCl}_{4}$ solution $\left(C_{\mathrm{Au}}=1600 \mathrm{mg} / \mathrm{dm}^{3}\right)$ were added. The ratio of volumes of ethanol and ethylene glycol (ET:EG) was 1:3. The freshly cleaved mica plates (10 $\mathrm{mm} \times 6 \mathrm{~mm}$ ) were placed vertically in the glass vials with $5 \mathrm{ml}$ of growth medium. Formation of gold nanostructures was held during 24 hours at $80^{\circ} \mathrm{C}$. The reducing agent of gold ions is ET, since EG leads to reduction at higher temperatures of $120-165^{\circ} \mathrm{C}[38,39]$. In growth medium, Synthesis I Auprisms with triangular and hexagonal shapes are formed in free volume according to the results obtained earlier [37].

Immersing of mica plate into the growth medium changed the conditions of nucleation. Nuclei grow simultaneously in free volume (homogeneous nucleation) and on the surface of mica (heterogeneous nucleation). Quantity of NPrs on substrate depends on its surface conditions, in particular, on wettability of growth medium. The results of measurements of contact angle of surfaces of mica and annealed Au(111) according to the composition of the growth medium are presented in Table 1.

The contact angle of EG with mica surface is $\theta=30^{\circ}$, while ET droplet completely spreads on the surface. Adding PVP up to $45 \mathrm{mM}$ concentration in the mixture ET + EG changes the CA more than 2 times up to $41^{\circ}$ (against $19^{\circ}$ without PVP; see Table 1 ). It can be due to adsorption of PVP on mica surface.

Adding of $(0.5 \mathrm{mM}) \mathrm{HAuCl}_{4}$ to growth medium (see row 5 , Table 1) does not change the wetting of $\mathrm{Au}(111)$ surface while the contact angle for bare mica drops down to $17^{\circ}$. Thus, the surface of the gold film is completely wetted by growth medium (rows $2-5$ for Au (111) in Table 1), i.e. attraction between $\mathrm{Au}$ atoms and components of growth medium is sufficiently strong.

Exposition of mica plate in growth medium during 24 hours (see row

TABLE 1. Dependence of contact angle on the composition of the growth medium (Synthesis I).

\begin{tabular}{|c|c|c|c|}
\hline & \multirow{2}{*}{ Component } & \multicolumn{2}{|c|}{ Contact angle $\theta,^{\circ}$} \\
\hline & & $\mathrm{Au}(111)$ & Mica \\
\hline 1 & EG $(100 \%)$ & 38 & 30 \\
\hline 2 & ET $(100 \%)$ & $<9$ & $<9$ \\
\hline 3 & ET:EG $(1: 3)$ & $<9$ & 19 \\
\hline 4 & ET:EG (1:3), PVP (45 mM) & $<9$ & 41 \\
\hline 5 & ET:EG (1:3), PVP (45 mM), $\mathrm{HAuCl}_{4}(0.5 \mathrm{mM})$ & $<9$ & 17 \\
\hline
\end{tabular}




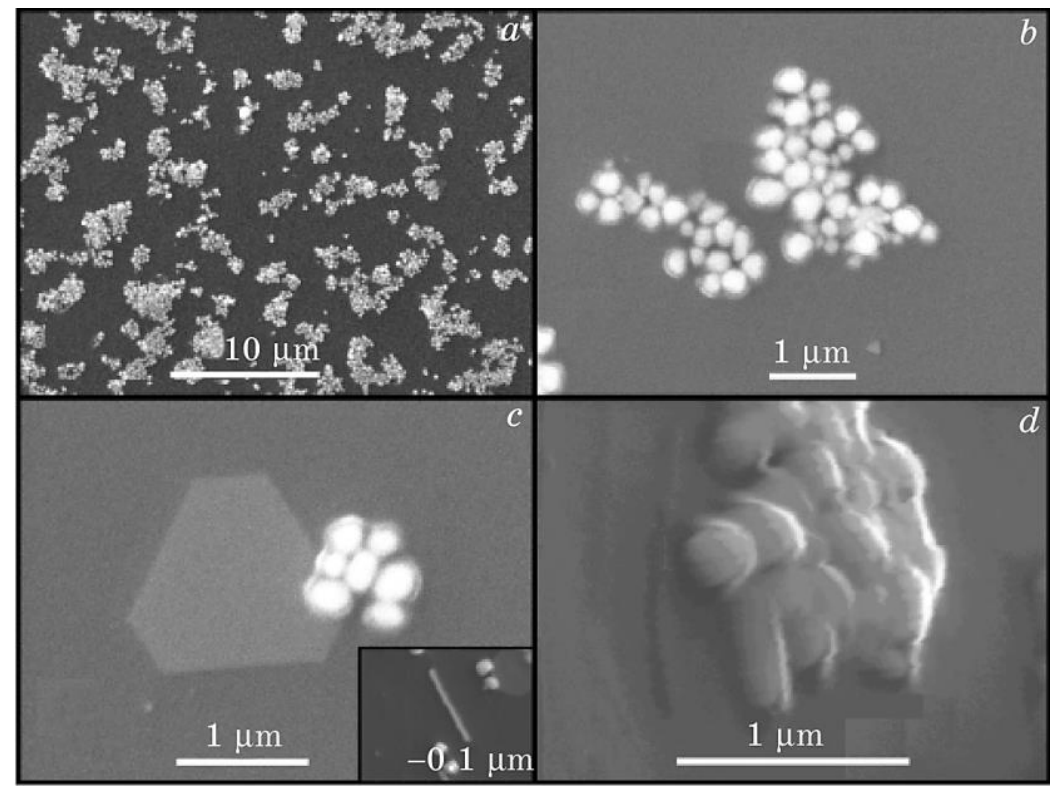

Fig. 1. SEM images of gold nanoparticles on mica surface: aggregates of nanoparticles $(a, b, d)$, nanoparticles, nanoprisms and nanowires $(c)$. The growth medium-ET:EG (1:3), $0.5 \mathrm{mM} \mathrm{HAuCl}_{4}, 45 \mathrm{mM}$ PVP; time of synthesis $t=24$ hours. In Figure 1, $d$, image was obtained at tilt of substrate to electron beam of $60^{\circ}$.

5 , Table 1) leads to the formation of gold nanostructures on its surface. One can see in SEM images (Fig. 1) that the surface of mica is preferentially covered by aggregates of Au NPs while flat NPrs and nanowires are rarely appeared (Fig. 1, c). The shape of the most nanoparticles is nearly spherical. The particles are covered by thin film of PVP stabilizer (grey 'aura' around NPs, Fig. 1, $b, c$ ). The adsorbed film prevents coalescence of NPs. However, some particles are self-assembled into aggregates depicted in Fig. 1, $d$ (the substrate is tilted to the direction of electron beam at $60^{\circ}$ ).

Synthesis II. In order to increase the number of gold NPrs per unit area, the conditions of synthesis were changed: (i) glycerol (G) was added in growth media, (ii) concentration of gold ions and time of synthesis ( $t=48$ hours) were increased. The growth medium contained ET:EG:G (6:7:7), $\mathrm{HAuCl}_{4}(1 \mathrm{mM})$ and PVP $(45 \mathrm{mM})$. Adding of $\mathrm{G}$ increases viscosity of dispersion medium. Table 2 demonstrates the dynamic viscosity $\eta$ of alcohols. At a temperature of $80^{\circ} \mathrm{C}$, the value of $\eta_{\mathrm{G}}$ exceeds $\eta_{\mathrm{ET}}$ more than 70 times.

On other hand, adding of $\mathrm{G}$ enhances wettability of mica surface. Table 3 shows the results of CA measurements of composition of the growth medium (Synthesis II) for surfaces of mica and annealed $\mathrm{Au}(111)$. 
TABLE 2. Temperature dependence dynamic coefficient of viscosity of alcohols [40].

\begin{tabular}{c|cc}
\hline \multirow{2}{*}{ Alcohol } & \multicolumn{2}{|c}{ Dynamic viscosity $\eta, \mathrm{mPa} \cdot \mathrm{s}$} \\
\cline { 2 - 3 } & $20^{\circ} \mathrm{C}$ & $80^{\circ} \mathrm{C}$ \\
\hline ET & 1.2 & 0.435 \\
EG & 19.9 & 3.2 \\
G & 1480 & 35 \\
\hline
\end{tabular}

In contrast to the system of ET:EG (1:3), the surface of mica is well wetted by growth medium ET:EG:G (6:7:7), which contains of PVP and $\mathrm{HAuCl}_{4}$ (compare rows 4, 5 of Table 1 and 3 ). We consider that polymer molecules and $\mathrm{AuCl}_{4}^{-}$ions are more easily attached to the surface of mica under such conditions. The number of nucleation centres increases, and, as a result, the quantity of NPrs increases. This hypothesis was experimentally confirmed.

Figure 2 shows a typical SEM image of the synthesized Au NP and NPr on surface of mica. The most of nanostructures that are randomly distributed on the substrate demonstrate regular triangle and hexagonal shape or triangles with truncated vertices. To remove particles, which were attached to surface from free volume, the plate of mica was rinsed in distilled water.

The element composition of the substrate and NPrs was investigated. Semi-quantitative microprobe analysis was carried out by EDS. The results are presented in Table 4 . The analysis has shown that the mica substrate includes $\cong 46 \% \mathrm{SiO}_{2}, \cong 34 \% \mathrm{Al}_{2} \mathrm{O}_{3}$ and minor impurities of $\mathrm{Na}_{2} \mathrm{O}, \mathrm{MgO}, \mathrm{K}_{2} \mathrm{O}, \mathrm{TiO}_{2}$ and $\mathrm{FeO}$ (Table 4, columns 2, 5). The data are in a good agreement with the literature [41].

Energy dispersive spectrum of prism at the point 1 (Fig. 2,b) indicates $100 \%$ of gold (Table 4 , column 1), i.e., investigated nanoprism is formed by gold. The thickness is large enough to prevent penetration

TABLE 3. Dependence of contact angle on the composition of the growth medium (Synthesis II).

\begin{tabular}{|c|c|c|c|}
\hline \multirow{2}{*}{\multicolumn{2}{|c|}{ Component }} & \multicolumn{2}{|c|}{ Contact angle $\theta,^{\circ}$} \\
\hline & & $\mathrm{Au}(111)$ & Mica \\
\hline 1 & G (100\%) & 37 & 21 \\
\hline 2 & EG $(100 \%)$ & 38 & 30 \\
\hline 3 & ET:EG:G (6:7:7) & $<9$ & $<9$ \\
\hline 4 & $\begin{array}{l}\text { ET:EG:G ( } 6: 7: 7), \\
45 \text { mM PVP }\end{array}$ & $<9$ & $<9$ \\
\hline 5 & $\begin{array}{c}\text { ET:EG:G (6:7:7), } 45 \mathrm{mM} \\
\text { PVP, } 1 \mathrm{mM} \mathrm{HAuCl}_{4}\end{array}$ & $<9$ & $<9$ \\
\hline
\end{tabular}




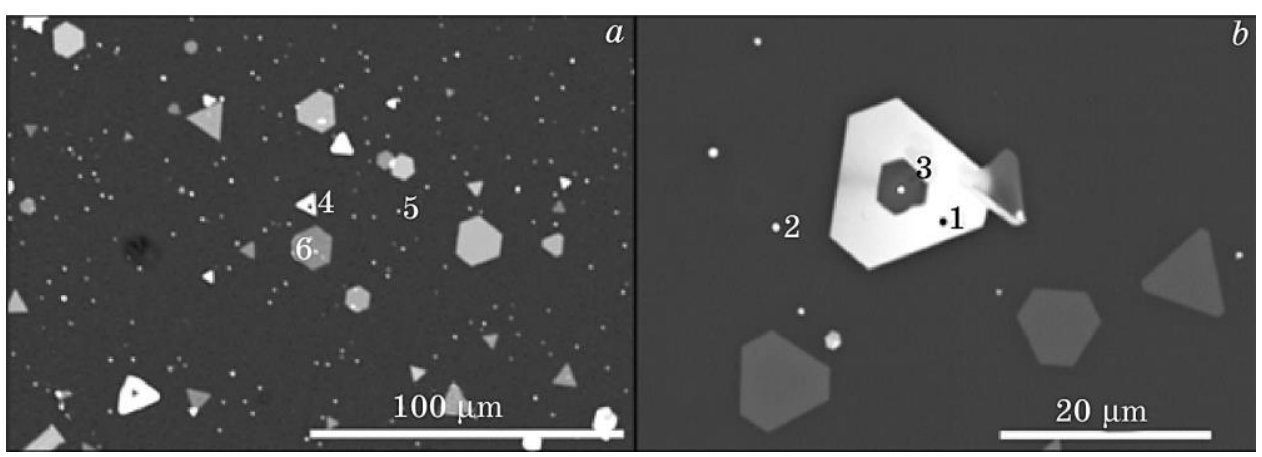

Fig. 2. SEM images of gold NPs and NPrs on the surface of mica after rinsing in distilled water. The growth medium-ET:EG:GL (6:7:7), $1 \mathrm{mM} \mathrm{HAuCl}_{4}, 45$ mM PVP; synthesis time $t=48$ hours. Numbers denote the points, at which the energy dispersive spectra were taken: 1 and 4-the surface of the thick NPrs, 2 and 5-mica substrate, 3-the cavity inside NPrs, 6-a thin gold NPrs.

of electron beam. We also observed individual gold prisms with cavities inside (Figs. 2, $b$ and 3, $d$ ). The microprobe analysis (see point 3 of Fig. 2, $b$ and Table 4, column 3 ) showed that in addition to the lines corresponding to the elements of mica, there are low-intensity lines of gold. This indicates that cavity of the NPr contains a thin layer of gold.

In Figure $3, d$, one can easily see the steps of growth of nanoprisms, which correspond to the faces (110) and (100). The gold atoms are being trapped by kink of steps and form uncompleted layers. Thus, in the cavities, prism continues to grow.

TABLE 4. Results of semi-quantitative microprobe analysis of gold nanoprisms on mica surface.

\begin{tabular}{c|ccccccc}
\hline \multirow{2}{*}{$\begin{array}{c}\text { Elemental } \\
\text { composition, \% }\end{array}$} & \multicolumn{7}{|c}{ Point number } \\
\cline { 2 - 7 } & 1 & 2 & 3 & 4 & 5 & 6 \\
\hline $\mathrm{SiO}_{2}$ & 0.00 & 47.10 & 38.28 & 9.98 & 45.93 & 39.12 \\
$\mathrm{TiO}_{2}$ & 0.00 & 0.30 & 0.46 & 0.05 & 0.40 & 0.43 \\
$\mathrm{Al}_{2} \mathrm{O}_{3}$ & 0.00 & 33.30 & 27.46 & 8.23 & 35.78 & 29.02 \\
$\mathrm{FeO}$ & 0.00 & 1.70 & 2.28 & 2.50 & 1.61 & 2.42 \\
$\mathrm{MnO}$ & 0.00 & 0.00 & 0.03 & 0.30 & 0.00 & 0.17 \\
$\mathrm{MgO}$ & 0.00 & 2.30 & 1.82 & 0.75 & 2.21 & 1.85 \\
$\mathrm{Na}_{2} \mathrm{O}$ & 0.00 & 1.50 & 0.00 & 0.00 & 1.51 & 1.14 \\
$\mathrm{~K}_{2} \mathrm{O}$ & 0.00 & 13.80 & 16.75 & 13.22 & 12.56 & 15.93 \\
$\mathrm{Au}$ & 100 & 0.00 & 12.92 & 64.97 & 0.00 & 9.92 \\
$\mathrm{Sum}$ & 100 & 100 & 100 & 100 & 100 & 100 \\
\hline
\end{tabular}




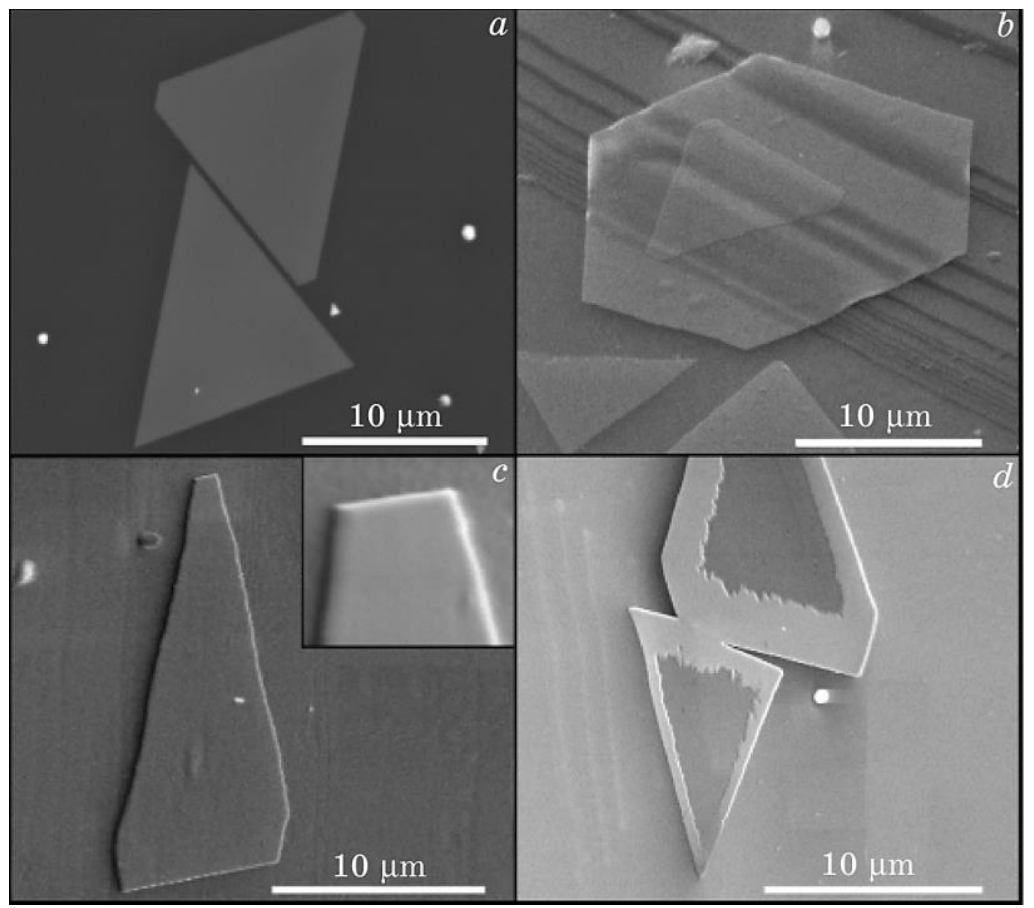

Fig. 3. SEM images of triangle and hexagonal gold NPrs, prism and insert of its top $(c)$, SEM images of the cavity in nanoprisms $(d)$. Images $(c, d)$ obtained at tilt of substrate to electron beam of $60^{\circ}$.

The growth mechanism of Au NPs and NPrs under conditions of polyol synthesis can be considered within the LaMayer model [42]. At the first stage, $\mathrm{AuCl}_{4}^{-}$ions reduce to $\mathrm{Au}^{0}$. The seeds are formed at the sites of maximum concentration of $\mathrm{Au}^{0}$ in the free volume of dispersion medium or on the surface of the substrate. Every seed can decay, if its size is less than critical, or continue to grow, if size exceeds critical. The growth of particles is limited by the rate of formation of gold atoms because of the chemical reaction and by their diffusion up to/on the surface of NPs.

The shape of NPs strongly depends on presence of defects in seeds and adsorption of PVP molecules. Among the seeds that obtained via the citrate method, authors [43] identified single crystalline, planartwinned, penta-twinned and complex multiply twinned structures. The maximum yield of flat hexagonal Au NPrs was obtained in mixtures of water-methanol- $\mathrm{HAuCl}_{4}$ and $\mathrm{PVP}$, which contained the largest number of planar-twinned seeds [43]. This result confirms the theory of Lofton, Sigmund [44], who proposed a growth mechanism of large planar prisms. According to [44], the twin (111) planes of the $\mathrm{Au}$ and $\mathrm{Ag}$ nuclei direct the growth of NPs into prisms or plates with a high aspect 
ratio. The reason for this is the formation of 're-entrant grooves', which are the sites of adatoms attachment, and lead to the formation of a new atomic layer in this region, i.e., prism grows laterally.

Nanoprisms of gold with lateral dimensions of several microns (Figs. 2,3 ) are formed on the surface of mica under the conditions of Synthesis II. To reveal a possible role of Lofton-Sigmund mechanism in formation of flat NPr, we used SEM for thorough study of side faces of NPr (Fig. 3, c). Concave shape of side faces should give noticeable contrast in the image of different parts of these faces. We cannot find any NPr with such a contrast in this experiment. The lateral faces of nanoprisms do not have grooves. On this basis, we supposed that formation of flat NPr in our experiments is mainly connected with the difference of adsorption of PVP on gold faces. However, in order to establish finally the mechanism of NPrs formation, additional studies are needed, in particular, studies of the shape and defects of gold seeds formed on the surface of mica under the conditions of polyol Synthesis II.

What is the role of PVP in formation of Au prisms? First, PVP molecules are adsorbed on the substrate defects and change the surface conditions for fixation of $\mathrm{AuCl}_{4}^{-}$ions on it and further formation of seed. Molecules of PVP are able to coordinate with $\mathrm{AuCl}_{4}^{-}$before reduction, forming a complex $\mathrm{PVP} / \mathrm{AuCl}_{4}^{-}$[45]. Such complexes can also be fixed on the surface of mica. In the complexes $\mathrm{PVP} / \mathrm{AuCl}_{4}^{-}$, gold ions are reduced under more 'soft' conditions and form Au clusters of smaller diameter with a narrow size distribution in comparison with the system without PVP. An important role in the synthesis of Au NPrs is performed by the pyrrolidone ring [43]. The bond of PVP with Au surface is formed by unshared electron pair of oxygen and nitrogen of pyrrolidone ring that was confirmed by micro-Raman spectroscopy [37].

Second, a number of researchers indicate [46-48] that PVP molecules are adsorbed on the (111) faces of Au NPrs, blocking their growth in [111] direction. Therefore, growth of NPrs occurs in lateral direction and their thickness is in range of tens of nanometers. In [43], NanoSIMS method was used for determining the location of PVP molecules on $\mathrm{Au}$ NPrs. It was found that PVP adsorbs predominantly around the perimeter of NPrs at concentration $C_{\mathrm{PVP}}=0.4 \mathrm{~g} / \mathrm{dm}^{3}$. For the $C_{\mathrm{PVP}}=8 \mathrm{~g} / \mathrm{dm}^{3}$, adsorption of the polymer is observed both along the perimeter and on the (111) faces. In our experiments, the concentration of PVP in the growth medium is $5 \mathrm{~g} / \mathrm{dm}^{3}$. Therefore, we suppose that adsorption of polymer occurs intensively on the flat faces (111) and along the perimeter of NPr. The adsorbed PVP layer inhibits diffusion of $\mathrm{Au}^{0}$ atoms to the faces (111) of NPrs. Thus, the growth happens preferentially in the lateral direction. As a result, we observed the flat NPrs with lateral size up to $15 \mu \mathrm{m}$ (Fig. 3). Such objects have a maximum area of face (111) (Fig. 3,a). Removing stabilizer from this surface allows using NPrs as atomically flat substrates for STM [20, 
49]. The steps of mica substrate are clearly seen through the two NPrs (Fig. 3,b). This image confirms that the thickness of nanoprisms is in the nanometer range.

\section{CONCLUSIONS}

Influence of conditions of synthesis on formation of flat Au nanoprisms on mica surface has been studied. It is shown that, for Synthesis I nanoparticles, single prisms and nanowires of gold are formed on the surface of mica in a solution of ET:EG (1:3), $0.5 \mathrm{mM} \mathrm{HAuCl} \mathrm{HM}_{4}, 45$ $\mathrm{mM}$ PVP in contrast to the synthesis of only nanoprisms of gold in the free volume of the same growth medium [37].

Synthesis of $\mathrm{Au}$ NPrs on mica substrate is more efficient in the growth medium G:EG:ET (7:7:6) containing $45 \mathrm{mM}$ PVP and $1 \mathrm{mM}$ $\mathrm{HAuCl}_{4}$. Measurement of the contact angle showed that the wetting of the mica surface increases due to this growth medium. The number of nanoprisms per unit area of the surface increases, because of 1) an increase in the wettability of the mica surface owing to addition of glycerol, 2) an increase of concentration of $\mathrm{AuCl}_{4}^{-}$ions in the growth medium, and 3) an increase the number of seeds on the surface due to the effective fixation of $\mathrm{AuCl}_{4}^{-}$ions and the complexes PVP/ $\mathrm{AuCl}_{4}^{-}$.

\section{REFERENCES}

1. P. C. Chen, C. M. Sandra, and A. K. Oyelere, Nanotechnology, Science and Applications, 1: 45 (2008).

2. P. K. Jain, X. Huang, I. H. El-Sayed, and M. A. El-Sayed, Acc. Chem. Res., 41, No. 12: 1578 (2008).

3. S. S. Pekamwar, V. S. Deshmukh, and T. M. Kalyankar, IRJP, 6: 693 (2015).

4. P. Baptista, E. Pereira, P. Eaton, G. Doria, A. Miranda, I. Gomes, P. Quaresma, and R. Franco, Anal. Bioanal. Chem., 391, No. 3: 943 (2008).

5. J. Hu, Z. Wang, and J. Li, Sensors, 7, No. 12: 3299 (2007).

6. X. Huang, P. K. Jain, I. H. El-Sayed, and M. A. El-Sayed, Lasers. Med.Sci., 23: 217 (2008).

7. X. L. Luo, J. J. Xu, Y. Du, and H. Y. Chen, Anal. Biochem., 334, No. 2: 284 (2004).

8. M. E. Stewart, C. R. Anderton, L. B. Thompson, J. Maria, S. K. Gray, J. A. Rogers, and R. G. Nuzzo, Chem. Rev., 108: 494 (2008).

9. J. Kern, R. Kullock, J. Prangsma, M. Emmerling, M. Kamp, and B. Hech, Nat. Photonics, 9: 582 (2015).

10. C. Huck, A. Toma, F. Neubrech, M. Chirumamilla, J. Vogt, F. De Angelis, and A. Pucci, ACS Photonics, 2, No. 4: 497 (2015).

11. J.-S. Huang, V. Callegari, P. Geisler, C. Brüning, J. Kern, J. C. Prangsma, X. Wu, T. Feichtner, J. Ziegler, P. Weinmann, M. Kamp, A. Forchel, P. Biagioni, U. Sennhauser, and B. Hecht, Nat. Commun., 1: 350 (2010).

12. Z. Liu, F. Xue, Y. Su, Y. M. Lvov, and K. Varahramyan, IEEE Trans. Nano- 
technol., 5, No. 4: 379 (2006).

13. R. K. Gupta, G. Ying, M. P. Srinivasan, and P. S. Lee, J. Phys. Chem. B, 116, Iss. 32: 9784 (2012).

14. W. Xu, J. S. Kong, and P. Chen, Phys. Chem. Chem. Phys., 11: 2767 (2009).

15. M. Haruta, Gold Bulletin, 37: 27 (2004).

16. H. Masatake and D. Masakazu, Appl. Catal. A, 222, Nos. 1-2: 427 (2001).

17. M. Fana, G. F. Andrade, and A. G. Brolo, Anal. Chim. Acta, 693, Nos. 1-2: 7 (2011).

18. T. I. Borodinova, V. G. Kravets, and V. R. Romanyuk, J. Nano- Electron. Phys., 4, No. 2: 02039 (2012).

19. E. S. Shibu, K. Kimura, and T. Pradeep, Chem. Mater., 21: 3773 (2009).

20. D. H. Dahanayaka, J. X. Wang, S. Hossain, and L. A. Bumm, J.Am. Chem. Soc., 128, Iss. 18: 6052 (2006).

21. P. R. Sajanlal and T. Pradeep, J.Chem. Sci., 120, No. 1: 79 (2008).

22. B. Radha, M. Arif, R. Datta, T. K. Kundu, and G. U. Kulkarni, Nano Res., 3, No. 10: 738 (2010).

23. T. K. Sau and C. J. Murphy, J.Am.Chem. Soc., 126: 8648 (2004).

24. J. E. Millstone, S. Park, K. L. Shuford, L. Qin, G. C. Schatz, and C. A. Mirkin, J.Am. Chem. Soc., 127, Iss. 15: 5312 (2005).

25. J. E. Millstone, G. S. Métraux, and C. A. Mirkin, Advanced Functional Materials, 16, No. 9: 1209 (2006).

26. D. Lee, S. Hong, and S. Park, Bull. Korean Chem. Soc., 32, No. 10: 3575 (2011).

27. L. Scarabelli, M. Coronado-Puchau, J. J. Giner-Casares, J. Langer, and L. M. Liz-Marzán, ACS Nano, 8, No. 6: 5833 (2014).

28. V. R. Estrela-Llopis, T. I. Borodinova, and I. N. Yurkova, Nano-Science: Colloidal and Interfacial Aspects (Ed. V. M. Starov) (London-New York: CPC Press Taylor Francis Group: 2010), p. 307.

29. T. Ogi, N. Saitoh, T. Nomura, and Y. Konishi, J. Nanopart. Res., 12: 2531 (2010).

30. S. S. Shankar, A. Rai, B. Ankamwar, A. Singh, A. Ahmad, and M. Sastry, Nat. Mater., 3: 482 (2004).

31. V. C. Verma, S. K. Singh, R. Solanki, and S. Prakash, Nanoscale Res. Lett., 6: 16 (2011).

32. A. Miranda, E. Malheiro, E. Skiba, P. Quaresma, P. A. Carvalho, P. Eaton, B. De Castro, J. A. Shelnutt, and E. Pereira, Nanoscale, 2, No. 10: 2209 (2012).

33. H.-C. Chu, C.-H. Kuo, and M. H. Huang, Inorg. Chem., 45, No. 2: 808 (2006).

34. F. Kim, S. Connor, H. Song, T. Kuykendall, and P. D. Yang, Angew. Chem. Int. Ed., 43: 3673 (2004).

35. C. C. Li, W. P. Cai, B. Q. Cao, F. Q. Sun, Y. Li, C. X. Kan, and L. D. Zhang, Advanced Functional Materials, 16, No. 1: 83 (2006).

36. H. Liuab and Q. Yang, Cryst. Eng. Comm., 13: 2281 (2011).

37. T. I. Borodinova, V. I. Sapsay, and V. R. Romanyuk, J. Nano- Electron. Phys., 7, No. 1: 01032 (2015).

38. C. Wang, C. Kan, J. Zhu, X. Zeng, X. Wang, H. Li, and D. Shi, J. Nanomaterials, 2010, Article ID 969030 (2010).

39. M. Tsuji, N. Miyamae, M. Hashimoto, M. Nishio, S. Hikino, N. Ishigami, and I. Tanaka, Colloids Surf. A, 302, Nos. 1-3: 587 (2007).

40. N. B. Vargaftik, Spravochnik po Teplofizicheskim Svoistvam Gazov i Zhidkostey [Handbook of Thermophysical Properties of Gases and Liquids] (Moscow: Nau- 
ka: 1972) (in Russian).

41. K. I. Volkov, P. N. Zagibalov, and M. S. Metsik, Svoistva, Dobycha i Pererabotka Slyudy [Properties, Extraction and Processing of Mica] (Irkutsk: VostochnoSibirskoye Knizhnoye Izdatel'stvo: 1971) (in Russian).

42. V. K. LaMer and R. H. Dinegar, J.Am.Chem. Soc., 72, No. 11: 4847 (1950).

43. Y. Zhai, J. S. DuChene, Y. C. Wang, J. Qiu, A. C. Johnston-Peck, B. You, W. Guo, B. DiCiaccio, K. Qian, E. W. Zhao, F. Ooi, D. Hu, D.Su, E. A. Stach, Z. Zhu, and W. D. Wei, Nat. Mater., 15, No. 8: 889 (2016).

44. C. Lofton and W. Sigmund, Advanced Functional Materials, 15: 1197 (2005).

45. T. Yonezawa and N. Toshima, J. Chem. Soc. Faraday Trans., 91: 4111 (1995).

46. M. Tsuji, M. Hashimoto, Y. Nishizawa, M. Kubokawa, and T. Tsuji, Chem. Eur. $J ., 11: 440$ (2004).

47. C. Li, W. Cai, Y. Li, J. Hu, and P. Liu, J.Phys. Chem. B, 110, No. 4: 1546 (2006).

48. J. E. Millstone, S. J. Hurst, G. S. Métraux, J. I. Cutler, and C. A. Mirkin, Small, 5, No. 6: 646 (2009).

49. W. D. Tennyson, C. E. Allen, D. R. Freno, D. H. Dahanayaka, and L. A. Bumm, Microscopy and Microanalysis, 14, Iss. S2: 22 (2008). 